\title{
The Impact of Delegated Authority and Organizational Commitment toward Budget Participation
}

\author{
Ernawaty Usman, Nurhayati Haris, Sugianto \\ Tadulako University \\ ernawatyusman@untad.ac.id
}

\begin{abstract}
This study aimed to determine (1) the impact of participative budgeting towards local government performance, (2) the impact of delegation of authority towards local government performance, (3) the impact of organization commitment towards local government performance, (4) delegation of authority as independent variable, moderating variable or moderating quasi variable towards the local governance performance, and (5) organization commitment as independent variable, moderating variable, or moderating quasi variable towards the local governance performance. The results of research are Participation budget, delegation of authority and organizational commitment positively affects the performance of local government officials. Delegation of authority and organizational commitment is moderating variables but have the relationship is weak. Desentaralisasi system undertaken by governments daearah is good, it is seen by the delegation of authority that is applied in the process of budget participation.
\end{abstract}

Keywords-Participative budgeting; delegation of authority; organization commitment; local government performance and quasi moderasi

\section{INTRODUCTION}

Sector public even private organization in achieving the planned goals as effectively and efficiently need management controlling system. One of the primer elements in management controlling is budget. Budget is a statement about what is expected, planned or predicted to happen in a certain period which is planned to happen in the future (Lowe, 1970). Brownell (1982) define participative budgeting as a process in an organization includes the manager in determining budget goal which is being his responsibility.

APBD which is constructed based on performance is a budget system based on certain target that prime on efforts to achieve performance result in one period of budgeting. One of the function of budget is can be used as the assessment tool of performance, the expectation by the availability of participative budget is that the performance of local governance will be increased because all parties are given opportunity and directly involve in constructing budget in every sector. Argyris (1952) stated that the key of effective performance are if only the goals of that budget achieved, and the member participation hold the prominent contribution in achieving those goals.
The phenomenon which initiated this study is the ambiqu which shown the result about participative budget research towards managerial performance still being debatable and interesting enough to be explored, because the previous research stated that participative budget in one sight able to increase performance (research done by Brownell and Melness (1986), Chenhall and Brownell (1988), Mia (1989), Dunk (1990), Nauri and Pecker (1998) and Chong (2005). While another research discovered that participative budget unable to increase the managerial performance (research done by Bryan and Locke (1967), Milani (1975), Kenis (1979), Campbell dan Gingrich (1986) and Lukka (1988)). The clash of result creates an interest to do further research with contingency approach using delegation of authority and organization commitment as moderating variable.

Delegation of authority (authority delegating) is a given job process to someone whom eligible to do certain activity due to achieve organization goals. Hansen and Mowen (2000) states that decentralization is an authority delegation practice in making decision to the lower. Organization which adapts the principle of structural decentralization shows that top management will delegates the authority and responsibility in decision making to the lower manager. While organization commitment according to Robbin (2008) is a condition where employee feel included in organization and tries to develop to gain the goals. The strong organization commitment is a main tool to motivate employee to work harder so able to increase his performance, (Porter et. al., 1974).

\section{A. Research Issues}

Based on the explanation, so the problem of this study are:

1) Does participative budget give a positive impact for local government performance.

2) Does delegation of authority give a positive impact towards local government.

3) Does organization commitment give a positive impact towards local government.

4) Does delegation of authority moderate the relation between participative budget with local government performance.

5) Does organization commitment moderate the relation between participative budget with local government. 


\section{LITERATURE REVIEW}

\section{A. Agency Theory dan Contigency Theory}

Agency theory according to Jensen and Meckling (1976) stated there's a relation of agency relationship in a company because the company is a collection of contracts between one or more parties as a supervisor (the principal) and to the other party as subordinates (agents). Agency theory has been used to explain participative budget. Managerial performance is expected to get improved, because the agent knows that his performance will be determined based on the appointed budget attainment degree. The analysis towards local government performance can be influenced by several contingency factors, while contingency theory stated that universally management accounting system will always suitable to be executed in every situation in the entire organization but management accounting system also affected by situational factors within the organization.

\section{B. Delegation of authority}

Delegation of authority is a process of job allocation to another legitimate person to do certain activities due to achieve the organization goals. Stoner et. al. (1996:41) explained that authority is a form of sovereignty, oftentimes used to widely refer on human capability in using sovereignty as the result of certain characteristics such as knowledge and title/degree. Delegation of authority is a fundamental process within organization, because a supervisor will not be able to do all the things in terms of making decision. Hansen and Mowen (2000) declared that decentralization is a practice of delegation of authority in making decision to the lower agents.

\section{Organization Commitment}

Organization commitment according to Robbin (2008) is a condition where employee feels as the part of that organization and try to develop it to gain the appointed goals. Allen and Meyer (2003) stated that organization commitment is a concept consists of: affective commitment, continue commitment, and normative commitment.

\section{Participative Budget}

Participative budget is process where every individual involve inside and have an impact in constructing its performance budget which the target attainment will be evaluated, (Brownell, 1982). Participation is a process of decision making collectively with two or more parts, where such decision will have an effect in future to whom made it, or in another word the employee or bottom management who have a power in management process, Lubis (2010:228).

\section{E. Performance of Local Government Official}

Local government officer is the main actor in organization which being the main determinant in implementing organization operational. In a government, organization includes public sector organization such as working units (SKPD) which require official to improve its performance. Mahoney et . al . ( 1963) stated that managerial performance is the level of reliability or expertise manager in performing management functions such as; planning, organizing, directing, and monitoring. Performance is the result of quality and quantity that can be achieved by an employee in carrying out jobs in accordance with its responsibilities.

\section{F. Previous Research and Hypothesis Development}

This study is the following of research done by Ernawaty Usman (2013) who studied the model of participatory budget in supporting the performance of local government officials. The result shows a positive effect of participative buget on the performance of local government officials, with culture and organizational commitment affect the performance of local government officials. Ernawaty Usman (2013) found that participative budget has a positive effect on budget gap. Another observer such as: Dunk (1990), Nouri and Pecker (1998) and Chong (2005), Kusnariyanti and Imam Ghozali (2005), Jalaluddin and Dafi Bahri (2009) and Desak Putu Intan (2014) stated that participative budget has a positive impact on managerial performance. Another different result shown by Milani (1975), Kenis (1979), Lukka (1988), J Sumarno (2005), Dian Sari (2013), and Ria Yuliana (2014) states that participative budget doesn't have a impact on managerial performance.

\section{RESEARCH METHODOLOGY}

This research is a field research which is a research done by way of survey to collect data in order to obtain a depiction of the impact of delegation of authority and organization commitment to the relation between participative budget with the performance of local government officials. The research design used in this study is an explanation (explanatory research) because it is a study that describes causal relationship between variables through hypothesis testing, (Supomo and Indriantoro,2002: 92).

Sugiyono (2008:117) defines population as a generalization part consists of the object/subject that have certain qualities and characteristics defined by the researcher to be studied then drawn the conclusions. Population in this study is the working units (SKPD) in the city of Palu with the total is 175 . Sampling is done under approachment

(Slovin in Umar 1999: 67) as follows:

$$
\begin{aligned}
& \mathrm{n}=\frac{\mathrm{N}}{1+\mathrm{Ne}^{2}} \\
& \text { Note: } \\
& \mathrm{n}=\text { Sampel quantity } \\
& \mathrm{N}=\text { Population quantity } \\
& \mathrm{e}=\text { Error or failure rate (e) defined } 5 \% .
\end{aligned}
$$

There four variables used in this study, such as:

1. Participative budget, the instrument used to measure this variable is adopted from Milani (1975) with six question instruments with five Likert scale

2. Delegation of authority, measured by the instrument used by Gordon and Narayana (1984) with six questions with five Likert scale 
3. Organization commitment, measured by the instrument used by Mowday dkk, 1979 with nine questions with five points of Likert scale

4. Performance of local government official adopts question which is explored by Mahoney dkk (1963) measure by using 9 question instruments.

Data quality can be tested by conducting a test of reliability and validity. Reliability test is a tool to measure a questionnaire which is an indicator of a variable, while validity test is used to measure the legitimacy or validity of questionnaire. The questionnaire defined valid if the statement of questionnaire is able to express things that will be measured by the questionnaire. (Ghozali, 2009:49)

1. Multiple Linear Regression Analysis

The calculation of regression is using SPSS program and the following regression formula:

$$
\mathrm{Y}=\mathrm{b}_{\mathrm{o}}+\mathrm{b}_{1} \mathrm{X}_{1}
$$

$Y=$ Managerial performance,

$\mathrm{X}_{1}=$ Participative budget, $\mathrm{b}_{\mathrm{o}}=$ constant dan $\mathrm{b}_{1}=$ Regression coefficient

2. Interaction Test or Moderated Regresion Analysis (MRA) MRA is a multilevel linear regression analysis with interaction test approachment that can be defined into the following equation:

$\mathrm{Y}=\mathrm{a}+\mathrm{b}_{1} \mathrm{X}_{1}+\mathrm{b}_{2} \mathrm{X}_{2}+\mathrm{b}_{3} \mathrm{X}_{3}+\mathrm{b}_{4} \mathrm{X}_{1} \mathrm{X}_{2+} \mathrm{b}_{5} \mathrm{X}_{1} \mathrm{X}_{3}$

$\mathrm{Y}=$ Independent variable, $\mathrm{a}=$ constant, $\mathrm{b}_{1}-\mathrm{b}_{5}=$ regression coefficient and $\mathrm{X}_{1}-\mathrm{X}_{3}=$ Dependent variable

3. Classical Assumption Test

Classical assumption test was conducted by multicollinearity test, heteroskedastisitas test and normality test. Multicollinearity test can be performed by using the Pearson test with criteria, if the correlation between two variables is above 0.8 , then there will be multikol (Gujarati, 2006: 63). Heteroskedastisitas test aims to test whether in the regression model occurred inequality variance from residual of one observation to another observation. Normality test aims to test whether the regression model, or residual confounding variables have a normal distribution by viewing it through the normal probability plots which comparing the cumulative distribution with normal distribution.

$\mathrm{F}$ test is used to show whether all the dependent variables included in the model have a collective impact towards the independent variable. If the result of $F$ value calculation is greater than the value of $\mathrm{F}$ according to table, then Ho is declined and $\mathrm{Ha}$ is accepted, assuming a significance level $(\alpha)$ is $5 \%$

The t-test is to test the significant impact of independent variables towards dependent variable individually. If the result of $t$ value calculation is smaller than the value of $t$ according to table then Ho is accepted, whereas if t calculation is greater than $\mathrm{t}$ table then $\mathrm{Ho}$ is declined (Ha accepted). The basic assumption required in this case is the significance level $(\alpha)$ of $5 \%$

\section{RESUlt AND DisCUSSION}

\section{A. Results Of Testing Instruments}

There are two tests in the test instrument that is testing validity (validity test) and test the reliability (reliability). Testing these instruments is done with a view to determine valid and reliabel research instruments examined in this case is the Participation Budget, Delegation of Authority, Organizational Commitment, and Performance of Local Government officials.

\section{1) Validity test}

The questionnaire is said to be valid if the statement contained in the questionnaire were able to express something that is measured by the questionnaire (Ghozali, 2009). Validity can be determined by comparing the value correlated item-total correlation ( $\mathrm{r}$ count) of all the statements in each variable with critical $r$ value according to the criteria that is equal to 0.3 (Sugiyono, 2013) .Item statement questionnaire considered valid if the value of $r$ coun $t>r$ critical. The following statement of the validity of of research variables: Based on the results if the data found that the calculated value> critical value for each variable resarch, it can be concluded that all variables in this study Valid.

\section{2) Reliability test}

Reliability test is a device for measure a questionnaire which is an indicator of a variable. Questionnaires said to be reliable if the answer of the statement is consistent. Limit score Cronbach's Alpha reliability score of $<0: 50$ Category reliability is low, sufficient reliability score of $0.50-0.60$ category and a score above 0.70 to a high reliability (Jogiyanto, 2002). Cronbach's Alpha value for of research variables were tested using SPSS software showed Cronbach's Alpha value for the Budget Participation $\alpha=0.783$, performan

ce of local government officials $=0.762$ Delegation of authority for $\alpha=0.851$, and Organizational Commitment $\alpha=$ 0.771

\section{B. Classical Assumption Test Results}

\section{1) Multicollinearity Test}

Multikolinearitas a situation there is a correlation between the independent variables with each other. One way to detect multicollinearity is to use Person test. The correlation between the two variables exceeds 0.8 then there multikolinearitas (Gujarati, 2006). Based on the results if the data is the correlation between the two variables in this study declared free from multicollinearity due to the correlation of all variables in this study does not exceed 0.8 .

\section{2) 4.2.2. Heterokedasitas Test}

Heterokedasitas test aims to test whether the model residual variance occurs dissimilarity one observation to another observation. The regression model is good if there is no heteroscedasticity. Based on the results if the data on of research variables, the models are feasible for use in other words not happen heteroskedastisitas. 


\section{3) Normality Tes}

Normality Test aims to see whether the regression model, or residual confounding variables have a normal distribution with a view of the probability plot and compare the cumulative distribution with a normal distribution. Based on the results if the data we can see that the probability plots to meet the assumptions of normality.

\section{Hypothesis Testing And Discussion}

\section{1) The Multiple Regression Testing}

The test results of multiple regression showed that the value of Adjusted R Square of 0.236. Value Adjusted R Square shows that the transfer of functions and variables influence organizational commitment on the relationship between budgetary participation and performance of local 1 government officials by $23.6 \%, 76.4 \%$ explained by other variables not included in this research.

\section{2) F test}

$\mathrm{F}$ test was to show that all the independent variables included in the model have influence together against independen. The result of variable regression showed a significance level of 0.000 which means that the variable delegation of authority, organizational commitment and budgetary participation jointly affect the performance of local government officials.

\section{3) $T$ test}

The partial test used to test whether an independent variable contributes to the dependent variable. The partial test results in this study are shown in Table 4.1. the following:

TABLE I. T TEST RESUlts

\begin{tabular}{|c|c|c|c|c|c|c|c|c|c|c|}
\hline \multirow{3}{*}{ Lhd } & \multirow{2}{*}{\multicolumn{2}{|c|}{ 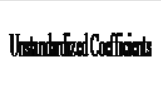 }} & \multirow{2}{*}{$\begin{array}{l}\text { Suntifited } \\
\text { Conffixit }\end{array}$} & \multirow{3}{*}{$t$} & \multirow{3}{*}{$\mathbb{S}_{\mathbb{T}}$} & \multicolumn{2}{|c|}{ 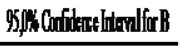 } & \multirow{2}{*}{ Condions } & \multirow{2}{*}{\multicolumn{2}{|c|}{ Cormaity ontitis }} \\
\hline & & & & & & , & & & & \\
\hline & B & Sillimu & Rat & & & & & Itavonde Prite Pat & Therex: & YII \\
\hline 1 (atat) & 225.176 & 412 & & 5463 & 0.000 & .36684 & $-18,22$ & & & \\
\hline$P A$ & 14.46 & $25 x$ & 5335 & 575 & 0.000 & 9.48 & 19.45 & $=[31 \quad 0.410 .457$ & 0.007 & 13338 \\
\hline ro & 2008 & 098 & 1294 & 2063 & Q04 & Q01 & 3975 & 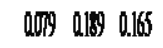 & 0.017 & 892 \\
\hline$P$ & 806 & 139 & 356 & 5785 & 0.000 & 5304 & 10.28 & Q0.93 0.450 .462 & 0.017 & $\$ 553$ \\
\hline Mll & 积 & 0060 & -1660 & 2006 & Q0OA & .200 & $: .102$ & $=0166-184 \quad-100$ & 0.009 & 10557 \\
\hline N & -46 & 000 & 520 & $.5 \mathrm{D}$ & 0000 & -690 & -311 & 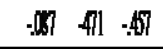 & 0.007 & $135 \mathrm{PM}$ \\
\hline
\end{tabular}

a. Source: the results of data processing, 2016.

\section{4) Testing Hypothesis 1}

The first hypothesis states that budget participation has positive influence on the performance of local government officials. The results of multiple regression analysis showed that budget participation has a positive relationship with a significance level of 0.000 , which means significantly so that it can be said that the hypothesis that budget participation has positive influence on the performance of local government officials is received. This positive relationship implies getting someone (local government officials) participated in the budget it will improve the performance of local government officials. The results are consistent with research conducted by Dunk (1990), Nouri and Pecker (1998), Chong (2005), Imam Ghozali and Kusnariyanti (2005), Jalaluddi and Dafi Bahri (2009) and urges Putu Intan (2014).

\section{5) Testing Hypothesis 2}

The second hypothesis states that delegation of authority positive effect on the performance of local government officials. The results of multiple regression analysis showed that the delegation of authority to have a positive relationship with a significance level of 0.000 , which means significantly so that it can be said that the second hypothesis is accepted. This positive relationship meaning that with the delegation of authority will improve the performance of local government officials. These results are consistent with research conducted by Matthew A. Abata (2014).

\section{6) Testing Hypothesis 3}

The third hypothesis states that delegation of authority moderate the relationship budgetary participation and performance of local government officials. The result of the interaction between delegation of authority and budgetary participation (M2) showed a negative correlation of (.476) with a significance level of 0.000 , which means significant. The test results indicated that the interaction of delegation of authority to moderate the effect of budget participation on the performance of local government officials, but has a weak relationship. Delegation of authority has a direct influence on the performance of local government officials, this means that delegation of authority is a quasi moderation. Quasi moderation means that delegation of authority as an independent variable and variable moderation. Under these conditions, the third hypothesis which states delegation of authority is accepted as a moderating variable. The results of this study is different from the research conducted by Suwarno, et all (2010).

\section{7) Testing Hypothesis 4}

The fourth hypothesis states that organizational commitment has positive influence on the performance of local government officials. The results of multiple regression analysis showed that organizational commitment has a positive relationship with a significance level of 0.041 , which means significantly so that it can be said that this hypothesis is accepted. This positive relationship implies getting someone (local government officials) have good organizational commitment that it will improve the performance of local government officials. The results are consistent with research conducted Wiwid Ambarwati (2013), Bambang Sardjito and Osman Muthaher (2007) and Diana Fibrianti and Iksan Budi Rahardjo (2013).

\section{8) Testing Hypothesis 5}

Testing the fifth hypothesis which states that organizational commitment moderates the relationship budgetary participation and performance of local government officials. The result of the interaction between organizational commitment and participation of the budget (M1) showed a negative correlation of (0.126) with a significance level of 0.047 , which means significant. The test results indicated that the interaction of society together komitemn moderating 


\section{A trumens PRESS}

influence of budget participation on the performance of local government officials, but has a weak relationship. Organizational commitment has a direct influence on the performance of local government officials, this means that organizational commitment is a quasi moderation. Quasi moderation means that organizational commitment as an independent variable and variable moderation. Under these conditions, the fifth hypothesis which states undertaking by the organization as a moderating variable is received. These results are consistent with research conducted by Gunawan dan Santoso (2015).

\section{CONClusion AND SUGgestions}

Participation budget,delegation of authority and organizational commitment positively affects the performance of local government officials. Delegation of authority and organizational commitment is moderating variables but have the relationship is weak. Desentaralisasi system undertaken by governments daearah is good, it is seen by the delegation of authority that is applied in the process of budget participation. The presence of this delegation should go ahead with the permanent good coordination between supervisors and subordinates. Organizational commitment owned by local government officials has been excellent so that commitment needs to be maintained so that the future can organizations and growing.

\section{REFERENCES}

[1] Ambarwati dkk. 2013. Analisis Pengaruh Penerapan Prinsip Good Coorporate Governance dan Komitmen Organisasi Terhadap Kienrja Aparatur Pemerintah. SNA XVI. Manado 25-28 September 2013.

[2] Allen dan Meyer, (2003), Commitment in the Workplace (Theory Research and Aplication). London: Sage Publication.

[3] Argyris, C,(1952), The Impact Budget on People, The Controllership Foundation, Inc, The Scool of Business and Public Administration, Cornell University.

[4] Bambang Sardjito dan Osman Muthaher. 2007. Pengaruh Partisipasi Anggaran Terhadap Kinerja Aparat Pemerintah Daerah : Budaya Organisasi dan Komitmen Organisasi Sebagai Variabel Moderating. SNA X, Unhas Makassar 26-27 Juli 2007.

[5] Brownell P., 1982. A Field Study Examination Of Budgetary Participation and Locos Of Countrol. The Accounting Review, Vol.57, No. 4, October 1982, 766777.

[6] Brownell P., and Mclnnes, 1986, Budgetary Partisipation, Motivation and Managerial Perfomance, The Accounting Review, Vol. LX14, October 587-600.

[7] Brownell, P. 1982. Participation in The Budgeting Process. When it Works and When Doesn't. Journal Accounting Literature, Vol 1.

[8] Chenhall, H.R and Brownell, 1988. The Effect of Participative Budgeting On Job Satisfaction and Perfomance Role Ambiguity as Intervening Variablel, Accounting Organizations and Society, Vol 13 No 3. Pp 225-233.

[9] Chong K, 2005. The Impact of Market Competition and Budgetary Participation on Perfomance and Job Satisfaction. A Research Note, The British Accounting Review Vol 37. Pp 115-133.
[10] Campbell, DJ and K.F. Gongrich 1986. The Interactive Effect Of Task Complexity and Partisipation on Task Perfomance. A Field Experiment. Organization Behavior and Human Decision Process. Pp 162-168.

[11] Desak Putu Intan, dkk 2014. Pengaruh Akuntanbilitas, Kejelasan Sasaran Anggaran dan Partisipasi Anggaran Terhadap Kinerja Manajerial Satuan Kerja Perangkat Daerah. E Journal S1 Akuntansi Pendidikan Ganesha Vol.2 No.1 Tahun 2014.

[12] Dian Sari.2013. Pengaruh Partisipasi Anggaran dan Akuntansi Pertanggungjawaban Terhadap Kinerja Manajerial PT. Pos Indonesia. E. Jurnal Binar Akuntansi. Volume 2 No.2 Januari 2013.

[13] Dunk S.A1990. Budgetary Participation, Agreement on Evaluation Criteria and Managerial Perfomance. A Research Note. Accounting Organizations and society, vol. 13 No.3 pp. 171-178

[14] Diana Fibrianti dan Iksan Budi Raharjo.2013. Pengaruh Partisipasi Anggran, Desentralisasi, Komitmen Organisasi dan Ketidakpastian Ligkungan Terhadap Kinerja Manajerial. Jurnal Ilmu dan Riset Akuntansi, Vol.1 Nomor 1, Januari 2013.

[15] Ernawaty Usman dan Selmita P. 2013. Anggaran Partisipatif dalam Menunjang Kinerja Aparatur Pemerintah Daerah. Jurnal Akuntansi Multi Paradigma, Volume 4, Nomor 1, April 2013

[16] Ernawaty Usman, Semita P dan Sugianto. 2012. Analisis Budaya Organisasi dan Komitmen Organisasi dalam Senjangan Anggaran. Jurnal Akuntansi Multi Paradigma, Volume 3, Nomor 3, Desember 2012

[17] Gordon dan Narayana, 1984. Management Accounting System, Perceived Environmental Uncertainty and Organization Structure; an empirical analysis. Journal Accounting, Analysis and Society., Volume 9 No.4,1984

[18] Gozali, Imam, 2002, Aplikasi analisis Multifariat dengan program SPSS, BP, Undip.

[19] Gujarati Damodar. 2006. Dasar - Dasar Ekonometrika. Erlangga.

[20] Gunawan dan Santoso. 2015. Pengaruh Partisipasi Anggaran Terhadap Kinerja Manajerial Melalui Komitmen Organisasi dan Motivasi Sebagai Variabel Moderasi. Jurnal Akuntansi Volume XIX, No.01 Januari 2105.Hal.144-159.

[21] Hansen Dan Mowen. 2000. Akuntansi Manajemen. Salemba Empat. Jakarta.

[22] J. Sumarno. 2005. Pengaruh Komitmen Organisasi dan Gaya Kepemimpinan Terhadap Hubungan Antara Partisipasi Anggaran dengan Kinerja Manajerial. SNA VIII Solo. 15-16 September 2005.

[23] Jalaluddin dan Dafi Bahri. 2009. Pengaruh Partisipasi Anggaran, Kejelasan Tujuan Anggaran dan Evaluasi Anggaran Terhadap Kinerja Aparat Pemrintah Daerah. Jurnal Telaah dan Riset Akuntansi Vol. 2 No.1 Januari 2009, hal. 44-53.

[24] Jensen, MC and W.H. Meckling, 1976. Theory of The Firm. Managerial Behaviour, Agency, Cost and Ownership Structure. Journal of Financial Economics,3,335-360.

[25] Kadek Juli Suardana Dan I Ketut Suryanawa, 2009. Pengaruh Partisipasi Penyusunan Anggaranpada Kinerja Manajerial Dengan Komitmen Organisasisebagai Variabel Moderasi.E Journal Universitas Udayana.

[26] Kenis, I. 1979. Effect of Goal Characteristics on Managerial Attitudes and Perfomance. The Accounting Review, 54:702-721.

[27] Lukka K, 1988. "Budgetary Biasing in Organization". Theoretical Framework and Empirical Evidence, Accounting Organization and Society 13. pp. $281-301$. 


\section{Atharris PRESS}

[28] Kusnariyanti dan Imam Ghozali. 2005. Analisis Pengaruh Partisipasi Anggaran Terhadap Kinerja Manajerial Melalui Komitmen Organisasi dan Job Relevant Information sebagai variabel Intervening. SNA VII Solo. 15- 16 September 2005.

[29] Lowe, E.A dan R.W. Shaw. 1968. An analysis of Managerial Biasing: Evidence From a Company's Budgeting Proces. The journal of Management Studies $: 304-315$.

[30] Lubis Arfan Ikhsan, 2010. Edisi 2.Salemba Empat. Jakarta.

[31] Matthew. A. Abata. (2014). Participative Budgeting and Management Performance In The Nigerian Food. Peoduct Sector.Global Journal of Contempoary In Accounting, Auditing and Business Ethics (GJCRA) An Online International Research Journal (ISSN-2311-3126).

[32] Mahoney, T.A., Jerdee, T.H. and Carroll, S.J. (1965). "The Jobs of Management", Industrial Relations, 4, pp. 97-110.

[33] Mia, L. 1989. The Impact of Participation In Budgeting and Job Difficultynon Managerial Perfomance and Work Motivation. A Reserach Note. vol. 14 No.4 pp. 347-357

[34] Milani, K. W. ,The Relationship of Participation in Budget-Setting to Industrial Supervisor Performance and Attitudes: A Field Study, The Accounting Review (April 1975), pp. 274-284.

[35] Maria Yanida dan Made Sudarma 2013. Pengaruh Partisipasi Anggaran Terhadap Kinerja Manajerial. Jurnal Akuntansi Multi Paradigma "JAMAL" Vol. 4. No.3,2013.
[36] Mowday R.T. 1992. Commitment Propensity, Organizational Commitment and Voluntary Turnover: A longitudional Study of Organizational Entry Process. Journal of Management, 18 (1):15-32.

[37] Nouri H. and Parker R. J. (1996), The Effect of Organizational Commitmenton The Relation Between Budgetary Participation and Budgetary.Behavioural Research In Accounting 8: 74-90.

[38] Nouri H. and Parker R. J. 1998), The Relationship between Between Budgetary Participation and Job Perfomance. Accounting Organization and Society.pp 4976.

[39] Ria Yuliana. 2014. Pengaruh Partisipasi Anggaran Terhadap Kinerja Manajerial Melalui Trust and Self Efficacy Sebagai Variabel Intervening. SNA 17 Mataram.

[40] Robbins, Stephen P, 2008 "Perilaku Organisasi “ Edisi Bahasa Indonesia, penerbit PT. Prenhallindo, Jakarta.

[41] Sugiyono . 2008. Statistik untuk Penelitian. Alfabeta, Jakarta.

[42] Supomo, B dan Indriantoro. 2002. Metodologi Penelitian Bisnis. Edisi I. Salemba Empat, Yogyakarta.

[43] Suwarno dan Kamila. 2010. Pengaruh Partisipasi Anggaran Terhadap Kinerja Manajerial dengan Motivasi dan Pelimpahan Wewenang sebagai Variabel Moderating. Jurnal Sorot, Vol 8. N0.2. Oktober. 2010.

[44] Stoner, 1996. Manajemen Jilid II. Edisi Indonesia, diterbitkan oleh PT.Bhuana Ilmu Populer.

[45] Umar. 2008. Desain Penelitian Akuntansi Keperilakuan. Raja Grafindo, Jakarta. 